\title{
Challenges Faced by the School Administration while Carrying out Various Welfare Practices on Secondary School Teachers in Bondo Sub-County, Kenya
}

\author{
Mr. Kennedy Omondi Otieno \\ Akoko Secondary School, Box 474 - 40601. Bondo \\ omondik@ymail.com

\section{Dr. Jack Odongo Ajowi*}

Jaramogi Oginga Odinga University of Science and Technology, Box 210 - 40601. Bondo

jackajowi@yahoo.com

\section{Prof. Joseph Bosire DVC (Academics)}

Jaramogi Oginga Odinga University of Science and Technology, Box 210 - 40601. Bondo

jbosire@jooust.ac.ke

Doi:10.5901/mjss.2015.v6n2p479

\section{Abstract}

The study sought to determine the teaching staff welfare practices and their effect on work performance of secondary schools teachers in Bondo Sub-County. The study was necessitated by discrepancy in work performance out put of the teaching staff as observed in achievements in curricular and co-curricular activities in secondary schools in Bondo Sub-County. The objectives of the study were to: assess the challenges faced by the school administration while carrying out various welfare practices and establish coping strategies employed by school administration to solve the challenges faced in offering the practices. The study was based on Social Action Theory which postulates that if a worker is not satisfied with the work environment, it will affect the services the worker renders to the institution. The research design for this study was descriptive survey design. A total of 330 respondents comprising of 240 teachers, 30 principals, 30 Board of Management chairpersons and 30 Parents Teachers Association chairpersons formed the population of the study. In each school, in the 30 chosen schools in Bondo Sub-county, eight teachers - two from each of the four departments, the principal, chairpersons of Board of Management and Parents Teachers Association were chosen for the study. The study used a combination of purposive sample and simple random technique to select the respondents. In conducting the survey, document analysis, three sets of questionnaires and interview schedule were drawn up. One set was administered to the Board of Management chairperson, the principal and the other set to the teaching staff. Information from Parents Teachers Association chairperson were obtained using interview schedule only. Research experts in the Department of Curriculum and Management at Jaramogi Oginga Odinga University of Science and Technology evaluated the instruments to ascertain their content validity. A pilot study was conducted in 10 percent of the population to test the reliability of the instruments. Simple descriptive statistics in form of mean rating, pie-charts and frequency counts using Statistical Package for Social Sciences was employed to analyze the data in order to establish relationship between the variables. The study was significant to educational practitioners and stakeholders and challenged them to adopt staff welfare practices that purely motivate the teaching staff hence enhancing their efficiency and effectiveness in discharging their duties. The study found out that welfare practices affect performance and productivity of teachers. From the findings, there emerged the need for welfare practices that purely motivate the teaching staff. The following were recommended for further research; government financial support \& its effect on school management and scheme of promotion \& its effect on teacher's performance.

Definition of Keywords: Teaching Staff, Welfare Practices and Work Performance

\section{Background to the Study}

Staff welfare practices were developed during the period of industrial revolution by early management authorities. Their philosophy was that, people's behavior in an organization depended on how they were treated (Owen, 2001). Every organization primarily needs committed and dedicated staff that will help the organization to meet its objectives. These objectives can only be achieved if the knowledge and skills of staff are upgraded through training and development (Porter, 2003). This will serve as a source of motivation to employees and drive them to contribute their quota towards the 
achievement of the organization's goals. According to Taylor (2000), competent staff at all levels of an organization is needed to effectively push ahead the objectives of the organization.

United States of America (USA) has experienced higher rate of teachers changing careers after a short time or do not enjoy their work - a consequence of poor staff welfare practices as seen in low pay, lack of support from educational bureaucracy and a pervasive isolation (Obama, 2006). Teachers have joined other professions with adequate staff welfare practices that enable them feel satisfied with the job. He reiterated that if we are serious about building a twentyfirst century school system, we must take the teaching profession seriously. Kelly (2007) had the same views in his study of job satisfaction among teachers in Michigan State but concluded that there is just one catch in exchange for all these practices - teachers need to become more accountable for their performance.

Canada as well as Spain has equally experienced teachers changing careers after a short time. A parliamentary commission set to form an inquiry into the practice of changing career in both countries has established that it is partly due to the welfare practices offered by different learning institutions (T00, 2007). Most teachers are not satisfied with the welfare practices offered in their respective working stations hence they opt for other jobs.

Study carried out by Lovell (2005) on welfare practices in United Kingdom (UK) ascertain that members of a particular group - working as a team, base their success on trust and encourage all members to express their opinions, varying views and questions. Similarly, they see conflict as a part of human nature and they react to it by treating it as an opportunity to hear about new ideas and opinions (Mullins, 2002). He added that everybody wants to resolve problems constructively. They participate equally in decision-making, but each member understands that the leader might need to make the final decision if the team can not come to a consensus.

In Nigeria, under the present government, the federal states have been allowed a greater part to play in the control of education, while the national government now has more of a coordinating role to play (Musaazi, 2002). The Federal Ministry of Education has administration and policy division that deals with cases of personnel management that includes staff appointments, promotions, leave tenure and retirements (Maicibi, 2003). Fafunwa (2002) in his case study of administration of education in Nigeria indicated that one of the most effective ways to bring about curriculum change, teaching improvement and the professional growth and development of teachers is through well-organized welfare practices such as in-service programmes and promotion of teachers within the education system either in terms of job group mobility or next working level.

In Uganda, the government recognized that education was a vehicle for national development and set up a commission that found that there was a need for a systematic identification of the needs of teachers so that the welfare practices programmes could be organized systematically (Castle Commission, 1963) as reported in Opolot (2006). The Commission also recommended large scale expansion of post primary schools. This involved construction of tuition blocks, staff houses and remunerating teachers properly for extra teaching loads. Lugamba (2001) while studying the development and administration of education in Uganda, observed that attaining the goal remained elusive until close to the end of the century when the authority begun to implement it.

A report by the Teacher's Service Commission (TSC, 2012) indicated that many teachers have left teaching in public schools for greener pastures - better paying private schools or the private sector. Oloo (2010) in his study on the effect of teaching and learning materials on performance in mathematics in secondary schools in Bondo district observed that the teacher's unions - Kenya Union of Post Primary Education Teachers (KUPPET) and Kenya National Union of Teachers (KNUT) have risen to the occasion by advocating for better pay for teachers and promotion for their respective members. However, he recommended that the unions should equally seek funds and time for continuous investment in in-service skills for its members (Oloo, 2010). This study intends to focus on staff welfare practices and their effect on work performance of teachers in secondary schools in Bondo district, an area that Oloo, in his study, did not explore.

Welfare practices are motivational avenues put in place by management in order to build confidence, create a sense of belonging and enhance productivity among workers in an organization. Institutions which have ignored these practices have recorded minimum productivity (Mullins, 2002). Despite various staff welfare practices such as job promotion, incentive packages, housing facilities, soft loan (imprest) to the teaching staff, team work, recognition of individual effort, in-service training, performance appraisal, lunch programme and fringe benefits that are offered in secondary schools in Bondo Sub-County, discrepancy in work performance out put in schools still remains a challenge. The study sought to determine the teaching staff welfare practices and their effect on work performance of secondary schools teachers in Bondo Sub-County.

The purpose of the study was to determine the teaching staff welfare practices and their effect on work performance of secondary schools teachers in Bondo Sub-County.

The study was guided by the following objectives: To determine the welfare practices in secondary schools in Bondo Sub-County. To find out the effect of welfare practices on work performance of teachers in secondary schools in 
Bondo Sub-County.To assess the challenges faced by the school administration while carrying out various welfare practices.To determine the coping strategies employed by school administration to solve the challenges faced in offering the practices.

This study was based on Social Action Theory by Robert Bowey, (1963) as indicated in Kelly (2010) who postulates that naturally, workers are not interested in any activity for its own sake, but rather for what the activity will bring them. People would be more ready to listen and co-operate with those who promised some kind of immediate reward than those who promised some better times in future. Hence concluding that provision of adequate social welfare services may increase the workers' job satisfaction and thus retaining their services towards work performance in school. Consequently, drawing from the literature reviewed in this study, the study was based on the understanding that various factors such as in-service training, promotion, performance appraisal, housing facilities, team-work, lunch programme, equity, fringe benefits, incentive packages and soft loan (imprest) to the teaching staff as independent variables (IDV) combine to influence work performance of teachers which is the dependent variable (DV) in a school.

\section{Research Methodology}

The study adopted the ex-post facto research design. Ex-post facto design is used in a situation whereby the independent variables (IV) and dependent variables (DV) have already interacted (Amin, 2005). Therefore, the researcher cannot manipulate the independent variable(s) with a view to determine its/their effect on the dependent variable(s). In this regard the effect of the interaction between the independent variables such as in-service training of teachers, promotion, performance appraisal, housing facilities, team-work, equity, fringe benefits, incentive packages, lunch programme and soft loan (imprest) to the teaching staff(s) determines retrospectively work performance of teachers - dependent variable (Creswell, 2009).

The study was carried out in Bondo sub-county which is one of the six districts in Siaya County in Kenya. It borders Lake Victoria to the west, Kisumu County to the east and Siaya district to the north. The district lies within longitude $33^{0}$ $20^{\prime}$ and $35^{\circ} 20^{\prime} \mathrm{E}$ and latitude $0^{\circ} 20^{\prime}$ and $0^{\circ} 50^{\prime} \mathrm{s}$. The district has a mean annual rainfall of $1530 \mathrm{~mm}$. (Republic of Kenya, 2012). The district covers an area of approximately 1,972 square $\mathrm{km}$. Out of this area; 1000 square $\mathrm{km}$ is covered by Lake Victoria. Bondo sub-county is divided into three administrative regions namely: Maranda, Nyang'oma and Usigu divisions. It has a population of 79,036 (Kenya Population and Housing Census, 2012). According to the census, Bondo Sub-County is fairly cosmopolitan and this provides respondents with different interest and background. The district relies heavily on agricultural activities such as fishing, quarrying, growing maize, beans, tomatoes and sand harvesting. According to a data obtained from County Education Office (2013), the sub-county has one National school, seven county schools and 26 registered districts schools.

A total of 330 respondents, which included, 240 teachers, that is eight teachers - two from each of the four departments namely examination, games, humanities and sciences, 30 principals, 30 Board of Management (B.O.M) chairpersons and 30 Parents Teachers Association (P.T.A) chairpersons formed the population of the study where the document data was collected from.

The number of Teachers, Principals, B.O.M and P.T.A Chair persons in Selected Secondary Schools in Bondo Sub-County

\begin{tabular}{ccccc}
\hline Division & Teachers & Principals & B.O.M Chairpersons & P.T.A Chairpersons \\
\hline Nyang'oma & 80 & 10 & 10 & 10 \\
Maranda & 96 & 12 & 12 & 12 \\
Usigu & 64 & 8 & 8 & 8 \\
Total & $\mathbf{2 4 0}$ & $\mathbf{3 0}$ & $\mathbf{3 0}$ & $\mathbf{3 0}$ \\
\hline
\end{tabular}

Source: Bondo Sub-County Education Office - Bondo, 2013

There were a total of 34 registered secondary schools in Bondo Sub-County. For the purpose of this study, 30 schools that had sat for KCSE examination and also participated in inter-school curricular and co-curricular activities in the subcounty were selected using purposive sampling. In Kenya, schools are stratified into Private and Public schools - Ministry of Education Science and Technology (MOEST, 2011). All the public schools which included one national, seven county and 22 sub-county schools were chosen for the study. In each school, in the 30 chosen schools in Bondo Sub-county, eight teachers - two from each of the four departments, the principal, chairpersons of Board of Management and Parents Teachers Association were chosen for the study. The study used simple random sampling to select one teacher each 
from examination, games, humanities and sciences departments and purposive sample technique to select departmental heads, principals, B.O.M and P.T.A chair persons of each school.

\section{Research Instruments}

The study used document analysis, three sets of questionnaires and interview schedule. One set was administered to the B.O.M chairperson, the principal and the other set to the teaching staff. Information from P.T.A chairperson was obtained using interview schedule only. However, analyzed documents such as inspection report, performance in co-curriculum and examination results were obtained from Bondo sub-county education office.

Validity is the degree to which results obtained from the analysis of the data actually represent the phenomenon under study (Creswell, 2009). If such data is a true reflection of the variables, then the inferences based on such data will be accurate and meaningful. Content validity which is a measure of degree to which data obtained from an instrument meaningfully and accurately represents content of a particular concept was determined by presenting them to two lecturers in the Department of Curriculum and Educational Management who are experts, to judge and advice on their content. Their inputs were used to make the necessary corrections on the instruments.

1. Reliability is a measure of the degree to which a research instrument yields consistent results or data after repeated trials. In this case, test-retest technique which involves administering the same instrument twice to the same group of respondents, usually after a time lapse between the first test and the second test was used (Orodho and Kombo, 2002). Reliability was ascertained through pilot study that was carried out in $10 \%$ of the population not necessarily under the study, after that the researcher corrected the inconsistencies and weaknesses detected in order to make it reliable.

Permission to conduct the research was sought from the university and the Government through the Ministry of Education. The researcher delivered the introduction letter to the school principals, sought official permission and booked an appointment before administering the instruments to the anticipated respondents. Upon receiving permission, the researcher administered the questionnaire to the respondents. The questionnaire was left with respondents for about one week to have adequate time to fill before collecting them. The researcher availed himself physically for interviews schedule and to help in case there is need for clarification or guidance.

2. Data collected using questionnaires was analyzed using simple descriptive statistics in the SPSS package of version 20 in form of mean rating, pie-charts and frequency counts. Borg (1996) observes that descriptive statistics are mathematical techniques for organizing and summarizing set of numerical data. The units of analysis were welfare practices in various schools and work performance out put such as early syllabus coverage, high achievement in school activities and in-depth syllabus coverage among the teachers. Content analysis was used to analyze responses from interviews schedule and open-ended parts of the questionnaires. According to Creswell (2009), in content analysis, a classification system is developed to record the information. In interpreting results, the frequency with which an idea appears was interpreted as a measure of importance or attention. Other responses were reported verbatim.

\section{Results and Discussions}

\subsection{Challenges Faced by the School Administration While Carrying out Various Welfare Practices}

The presentation on this section shows the challenges faced by the school administration while carrying out various welfare practices. The research question responded to was: what challenges does the school administration face in carrying out various welfare practices? The number of times a challenge is repeatedly mentioned indicated the level of importance the respondents attached it to the success of welfare practice. The pie charts below shows the challenges facing the school administration in its effort to offer various welfare practices. 


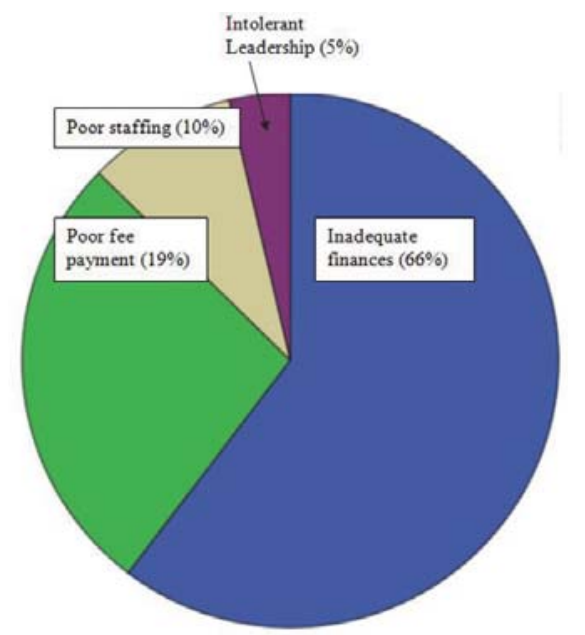

Bearing the welfare practices in mind, management (principals, P.T.A and B.O.M chair persons) was asked whether there are challenges facing the practices mentioned above. All the 30 principals and 30 B.O.M chair persons answered in the affirmative. In addition, all the respondents translating to $100 \%$ unanimously agreed that inadequate finances were posing one of the greatest challenges to the implementation of the welfare practices.

The pie charts clearly indicates that housing facilities in all the sub-county and some county schools followed by inservice of trained teachers are some of the welfare practices which are greatly affected by the inadequate finances. Similarly, 30 school principals representing all the respondents in that category asserted that inadequate finances in schools was majorly due to poor fee payment by parents and unreliable government financial support for Free Day Secondary Education (F.D.S.E).

One school principal intimated that in order to put up a two unit self-contained house for the teaching staff, approximately Ksh. 2.5 million is required. This amount may not easily be raised in many schools even through a fund drive. Therefore, other alternative ways of mobilizing for funds and infrastructural support should be explored. The respondents pointed out that availability of funds is a requirement to the implementation of welfare practices mentioned above.

The management of school in their response during the interview explained that most learning institutions do not have income generating projects. This has affected their ability to offer incentives to the teaching staff. For example, a school with projects such as poultry keeping, dairy and crop farming will comfortably give teachers incentives from these produce without going through the procedure of virement.

Some principals pointed out that low student enrolment in their schools coupled with poor fee payment and inadequate staffing are challenges faced by the school administration in its effort to offer welfare practices. Similarly, they noted that lack of support from B.O.M, P.T.A and the community affect their effort to bring staff together in the spirit of team work, consequently impacting negatively on the practices offered. Report from the sub-county education office (2011) indicated that a community invaded a school due to dismal performance in K.C.S.E results and blocked a principal from accessing the school. In the inspection report, many principals and teachers rebuked the barbaric act of the community. They suggested that the community should have contributed in putting in place measures that would have brought good results before pointing fingers at the school management. Teachers also noted that limited infrastructure in most schools is a challenge whose solution need to be sorted. The pie-chart below shows that $66 \%$ of the respondents agreed that indeed inadequate infrastructure in their institution is a challenge that needs to be addressed.

The management also mentioned that staff burn out is a challenge to team work and other welfare practices in the school. For instance, it would be difficult to appraise a staff member who has switched off. Certainly, he/she will be less productive and cooperative in joint school activities. These views were shared by $220(66 \%)$ of the respondents who pointed out that inadequate finances and infrastructure are the major challenges facing implementation of welfare practices. However, they added that burn out could be due to staff financial constrain as a result poor planning, over indulging in personal happiness, high expectation in life and domestic challenges. It could also be due to in ability to achieve personal targets either at home or at work place resulting into frustration. A keen analysis of the findings indicate that burn out transcends administrative boarders. This explains per excellence why both teachers and school principals have been involved in attempted suicide.

School principals and teachers in their response confirmed that they are faced with heavy work load since the 
school curriculum is over loaded. The demand for syllabus coverage, subject and school mean has put unprecedented pressure on both teachers and the principals. Very minimal time is left for benchmarking in order to discover what is happening elsewhere that need to be borrowed to improve work performance of teaching staff. Subsequently, they hardly have time to concentrate on policies that would put in place new welfare practices. In this sense, they end up ignoring important welfare practices in their stations.

\subsection{The Coping Strategies Employed by School Administration to Solve the Challenges Faced in Offering the Practices}

The research question responded to was: how does the school administration cope with the challenges faced in offering the welfare practices? The respondents were meant to identify the challenges and state the strategies employed to cope with the challenges. On the issue of inadequate finances due to poor fee payment by parents and unreliable government financial support for Free Day Secondary Education (F.D.S.E), most school principals advised their colleagues to initiate income generating projects. The project such as poultry keeping, running of school canteen, dairy and crop farming should be managed by staff welfare. The proceeds from these projects, wired to staff welfare kitty should be used to offer incentives to the teaching staff.

Moreover, the parents should be reminded about their obligation of timely fee payment and how it affects the learners in school. With the limited financial resources available in schools, many schools have opted to offer welfare practices that do not demand a lot of finances. Other practices are offered gradually depending on availability of funds.

All the respondents in this study were in agreement that there is a need to motivate the staff and put in place the necessary strategies to address the challenges facing welfare practices. Their responses are captured in table 4.3 below.

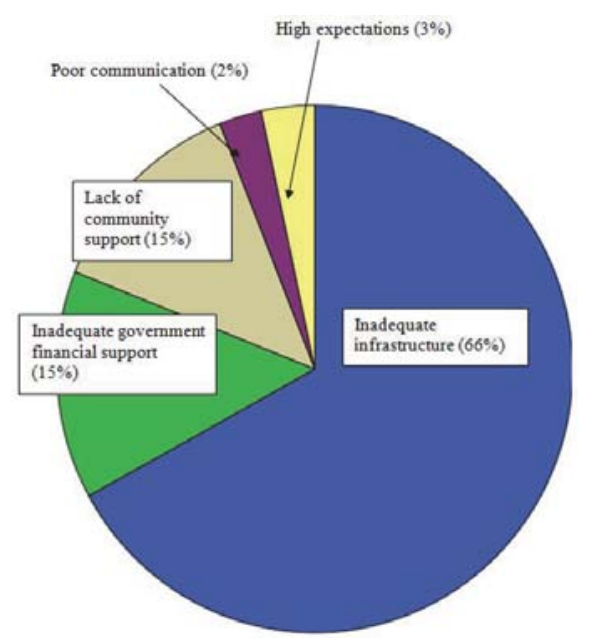

Table 4.3 Copping Strategies Employed in Selected Secondary School in Bondo Sub- County

\begin{tabular}{lcccc}
\hline Copping Strategies Employed by Schools & $\begin{array}{c}\text { CL.T } \\
\mathbf{n = 2 4 0} \\
(\mathbf{f})(\%)\end{array}$ & $\begin{array}{c}\text { SCH.P } \\
\mathbf{n = 3 0} \\
(\mathbf{f})(\%)\end{array}$ & $\begin{array}{c}\text { P.T.A } \\
\mathbf{n}=\mathbf{3 0} \\
\text { (f) (\%) }\end{array}$ & $\begin{array}{c}\text { B.O.M } \\
\mathbf{n}=\mathbf{3 0} \\
(\mathbf{f})(\%)\end{array}$ \\
\hline Staff motivation & 240100 & 30100 & 30100 & 30100 \\
Timely fee collection & 13757 & 30100 & 30100 & 30100 \\
Initiating income projects & 240100 & 30100 & 30100 & 30100 \\
Training of Teachers & 23096 & 2377 & 1137 & 1860 \\
Establishing culture of openness & 23096 & 1033 & 2480 & 2790 \\
Regular staffing & 12753 & 30100 & 30100 & 30100 \\
Benchmarking & 22092 & 1033 & 1314 & 2687 \\
Supportive administration & 240100 & 2997 & 2583 & 2583 \\
Sponsors and donors & 23598 & 2687 & 2377 & 2687 \\
Promotion scheme & 240100 & 1653 & 2067 & 2067 \\
Patience and understanding & 10745 & 30100 & 2893 & 2997 \\
\hline F = frequency, \% = percentage CL.T-class teacher, SCH.P- School principal & & &
\end{tabular}


Most teachers advocated for staff motivation, initiating income projects, supportive administration, promotion scheme, culture of openness devoid of intimidation and a strong staff welfare that bonds teachers together. They observed that teachers must be encouraged to create an environment that allows them to feel free and responsible. Similarly, they suggested a need for a leadership that accommodate everyone and offers guidance in the best way possible besides giving financial support to teachers when faced with critical moments. In their wisdom, if all these are done then the school management will have under its leadership a staff that is self driven, self motivated, focused and working towards a common goal. When asked whether it was possible to satisfy individual needs. The teachers responded that of course it was impossible; however, that element of showing concern from the leadership was important.

When management was asked whether they accept that training can improve staff performance and productivity, all the respondents responded in the affirmative. They noted that the main purpose of training is to enable the employees to overcome the limitations, current or anticipated that are causing an employee to perform at an undesirable level. In addition, all of them including the teachers agreed that training opportunities were available to staff. These opportunities are study leave with pay, study leave without pay, and in a few instances the government through TSC awards scholarship to the teaching staff. For the case of workshop and seminars for teachers, the school management would step in. Most of the respondents observed that even managers should attend training as part of a long-term strategy for the development of higher management skills.

The school managers also mentioned timely fee collection, initiating income projects, regular staffing to reduce teacher-student ratio as some of the coping strategies employed in various schools. However, they appealed to teachers to observe patience and great understanding based on the situation on the ground.

According to the principals, the institution have become increasingly complex, the time span between the current decision taken and outcome results have widened. Therefore, success in management of our institutions calls for strategic planning involving all the education stakeholders. This is the answer to numerous challenges facing welfare practices, added the principals.

\section{Summary, Conclusions and Recommendations}

\subsection{Summary}

\subsubsection{Challenges Faced by the School Administration While Carrying out Various Welfare Practices}

The study revealed that the school management faces myriad of challenges in its effort to offer welfare practices. The order in which they are listed reflected the frequency and intensity of their effect on the practices. These are:

In adequate finances due to poor fee payment and unreliable government financial support for F.D.S.E

Lack of income generating projects in schools resulting into difficulty in sustaining school activities that requires financial support.

In adequate infrastructure. Many school lack adequate tuition blocks, multipurpose hall, school farm and room for expansion. Teaching and learning of optional subjects are therefore affected negatively.

Excess teaching work load of teachers as a result of poor staffing. The few teachers posted by the government have over 35 lessons. This results into poor curriculum delivery.

In adequate support from B.O.M, P.T.A and the community. Most of the stakeholders in education are not pulling together in order to record success in education activities in school.

Staff financial constrains due to poor planning, over indulgence into personal happiness, high expectation, frustration and domestic challenges. In this regard, individual staff members suffer burn-out

Misunderstanding of current school situation and impatience from the teaching staff. Majority of members of staff do not understand the school financial situation particularly with the government financial support that is inadequate and unreliable.

Poor communication from top-bottom and bottom-top in a school set-up.

In tolerant school leadership that does not accommodate divergent views, criticism and offers no guidance and counseling to the teaching staff.

In equity and unfairness in the way the school management handles teachers and departments.

Lack of career advancement. Teachers stagnating in one job group for a long time resulting into job frustration hence burn out.

Stress; due to high teacher-student ratios that create extra work outside the normal working time.

Individual financial constraints. Many teachers are going through financial trying moments due to unprecedented 
economic inflations.

Uncooperative co-workers. In some school, team work is said but is not put to practice. The delivery of services collectively is therefore affected negatively.

\subsubsection{The Coping Strategies Employed by School Administration to Solve the Challenges Faced in Offering the Practices}

The findings in the study confirmed that many institutions were able to offer various welfare practices thanks to the coping strategies put in place. The following strategies were identified:

Initiating income generating projects such as poultry keeping, managing school canteen, dairy and crop farming.

The proceeds from these projects are wired to the staff welfare kitty and used to offer incentives to the teaching staff.

Constantly reminding parents about their fee payment obligation with an aim of enhancing timely fee payment.

Advocating for regular government financial support to F.D.S.E through teachers unions and Kenya Secondary

School Heads Association (KSSHA).

Organizing fundraising to boost teacher's welfare kitty.

Applying for C.D.F to fund some school projects and activities.

Putting in place internal teacher's promotion scheme based on performance and experience.

Mobilizing and soliciting for donors and sponsors to fill the gap resulting from inadequate government financial support. This will enable members of staff to meet their departmental financial requirement.

Promoting healthy interpersonal relationship among the personnel in the school setting.

Regular staffing through the government and B.O.M in order to improve teacher-student ratio.

Embracing leadership that accommodates every one and offers guidance in the best way possible.

Putting in place proper communication channel between the teachers and administration. Internal memos should be encouraged to keep staff members well informed about anticipated school activities and other emerging issues.

Advocating for a strong staff welfare that bonds teachers together. The management should embrace team work by involving everybody on board on matters concerning the school and getting involved in personal challenges such as wedding and bereavements which affect individual job performance.

\section{Conclusions}

The following conclusions were made:

Secondary schools in Bondo sub-county offer different teaching staff welfare practices depending on various reasons. The study noted that welfare practices have become a major issue in management in current times.

These practices affect work performance of teachers in their respective institutions.

The school administration encounters numerous challenges in offering various welfare practices.

Success of welfare practices offered in many institutions by the management and teachers depends on the coping strategies put in place.

Therefore, the existence of staff welfare practices is one of the factors contributing towards enhanced work performance among the teaching staff. These findings are in agreement with the Social Action Theory by Robert Bowey, (1963) as indicated in Kelly (2010) that guided this study. For all intents and purposes, in order to make an institution stronger, more effective and better able to cope with the challenging environment in which it doubtlessly exist, staff welfare practices is the answer.

\section{Recommendations}

The following recommendations were made:

There is need to improve the quality and relevance of education given to teachers in the universities and other institutions so that the training adequately prepares teachers for managerial responsibilities.

Education curriculum should be reviewed with an aim of removing unnecessary load and replacing it with emerging issues in order to make learning, teaching and management of education to be more current and relevant.

MOEST should organize in-service courses for school principals on staff welfare practices.

Teachers should observe great understanding and patience as the school managers offer welfare practices based on the situation on the ground.

TSC and MOEST should ensure that education policies that guarantees conducive working environment in schools 
are put in place.

The government should review its policy on F.D.S.E by increasing the amount given per student and disbursing the funds to schools in time.

\section{Suggestions for Further Research}

The study has the following suggestions for further research:

Undertake a study on the impact of government financial support on secondary school management.

Conduct a study to determine the teaching staff welfare practices and their effect on work performance of private secondary schools teachers in Kisumu city.

Conduct a study on TSC scheme of promotion and its effect on teacher's work performance in public secondary schools in Bondo sub-county.

\section{References}

Adeyemi, T.O. (2011). A Comparative Study of Students Performance in Secondary Schools in Odo and Ekifi States, Nigeria. (Online): Available.www.aceondo-ng.com. Accessed on $18^{\text {th }} .04 .2013$

Afullo, O.P.T. (2005). Role of the Teacher in Management of student Discipline in public schools in Bondo District. Unpublished Masters Thesis, Maseno University, Maseno.

Arumu, R. (2003). Judging school discipline: The crisis of moral authority. Harvard University press: ISBN 978-064011793.

Amin, M.E (2005). Social Science Research, Concept, Methodology and Analysis: 2nd Ed. Uganda: Makerere university.

Businge, P. (2004). Development of your staff; (Online): Available. www.staff development.com. Accessed on 18th.04.2013

Borland, M.V. \& Howsen, R.M. (2009). Staff Development Prctices (Online): Available. www.findarticles. Accessed on 26 th. 04.2013.

Borg, M. (2006). Emerging Issues in Primary Education. London: The Falmer Press.

Brainbridge, W. L. (2003). School Welfare Development Practices (On Line): Available. www.bainbridge.Edu. Accessed on $26^{\text {th }} .04 .2013$

Bush, T. (2003). Theories of Educational Leadership and Management. London: Sage Publications.

Cecil, P. (2008). Teaching of Life Sciences. New Delhi, Anmol Publication. Ltd.

Church, G.W. (2009). Rural Education: International Context. (Online). Available: www.answers.com.accessed on $20^{\text {th }} .04 .13$

Creative Research System (2010). The Survey System. Retrieved on $5^{\text {th }}$ April 2013 http://www.survey system.com

Creswell, J.W (2009). Research Design: (3rd ed.) Thousand Oaks. Sage

Chambers, G. (2003). Theories of Personality: Understanding Persons. New Jersey: Prentice Hall.

Campbell, M. (2003). Human Resource Management. London: Thomson Publishing.

Fafunwa, L. A. (2002). Information Literacy Competency Standards for Higher Education: http://www.ala.org/acr/comstan.html. Accessed on $26^{\text {th }} .04 .2013$

Gibbs, J.T. and Huang', L.N. (1991). Children of Colour Psychological Intervention with Minority Youth. San. Francisco: Jossey - bass.

Gicheru, M. (1979). Across The Bridge. Nairobi: Longhorn publishers.

Gay, N. (2002). Educational Research for Modern Scholars. Kenya: Froth Dimension Publishing Co. Ltd.

Guest, P. (2004). Development of Your Staff. London: Kogan.

Harris, M. \& Warner, M.. (2000). Human Resource Management. London: Thomson Publishing Company.

Hall, S. (2002). Management. $7^{\text {th }}$ ed. New York: John Wiley \& Sons.

Heneman, D. (2006). Management. Cincinnati: South Western Publishing.

Kathuri, M. (1993). Research Methods: Qualitative and Quantitative Approaches. Nairobi: Acts Press

Kelly. R. (2007). Human Resource Management $7^{\text {th }}$ ed. New York: Holt Reinhalt \& Winston. Inc

Kerlinger, F.N. (2003). Foundation of Behaviour Research. New York: Holt Reinhalt \& Winston. Inc

Kiumi, J.K. (2012). Towards a Theory of Managing Parent - School Conflict in Kenya. Paper Presented During Laikipia University $1^{\text {st }}$ International Conference Held in Laikipia University between 20th $23^{\text {rd }}$ June, 2012

Katumile, F. (2006). Girls and Women Education in Kenya: Gender Perspectives and Trends. Nairobi: UNESCO

Krejcie, R.V. \& Morgan, D. (1970). Determining Sample Size for Research Activities. Katumile, D. et al. (2010). Management. Cincinnati: South Western Publishing. Educational and Psychological Measurement, Vol.30, No.3.pp.607-610

Kajubi, K. (2011). Economic Survey Report. Nairobi: Government Printer.

KNEC. (2011). May 10: Peg Teachers Pay to Performance: East Africa Standard. P.6.

Lafasto, P. (2008). School Improvement after Inspection. School and LEA Responses. London: Sage Publications

Lovel, J. A. F. (2005). Management. $6^{\text {th }}$ ed. London Cambrige University Press.

Lugamba, P.L.(2001). Influence of Gender Stereotype on Girls and Performance in Mathematics in Secondary Schools in Butere Mumias Districts. Unpublished M. Phil. Thesis, Moi University, Eldoret, Kenya.

Mulwa, E. (2010). The Image of Education in 21st Century. Retrieved Feb. $2^{\text {nd }} 2013$ from http://www.emerging practices in education. co. ke.

Ministry of Education. (2011). Staffing in Education. Nairobi: ERAP

Mullins, L. J. (2002). Management and Organizational Behavior. (6th ed). Harlow: Prentice Hall. 
Musaazi, J.C.S. (2002). Theory and Practice of Educational Administration. Kampala. Net Media Publication. Ltd. Uganda Mutai, A. (2012). Teacher's Qualification Affect Academic Performance. The Daily Nation July 10 1 th pp 15. Nairobi: Nation Printers Muindi D.S (2012). Equity in learning: The gender dimension. Dar es salaamTanzania Mellisa, A. (2008). Achieving Universal Primary Education by 2015.A Chance for Every Child. Washington D.C. World bank. Maicibi, N.A (2003). Human Resource Management Success. Kampala. Net Media Publication. Ltd. Uganda Ministry of Education (2011). Kenya Certificate of Secondary Education 2011 Candidates Performance Report. Nairobi: KNEC Nyaga, T. (2010). Challenges Faced by School Administrators. Daily Nation, July 10th, 2012, p5. Nairobi: Nation Printers Obama B. (2006). Audacity of Hope: (2 ed.). New York: Mc Graw Hill, Inc. Ochieng' P. ( 2009). January 3rd. The Poor Fighting A losing Battle. Daily Nation P7. Nairobi: Nation Printers.

Ochieng', P. (2010). Teaching, Learning Material and its' Effect on Academic Performance: a case study of Secondary schools in Bondo Districts. Unpublished M.ed Thesis, Kampala International University, Kampala, Uganda.

Ojambo, T. (1998). Attitude of Parents in Secondary Schools in Samia. Bugweri. Unpublished M.Ed Thesis. Makerere University, Uganda.

Olembo G.A. (2010). Management in Education . (2nd ed.). Nairobi: Educational Research and Publication -ERAP.

Okuna, N. (2010). Nyanza Struggling to Make Academic Comeback. Teachers image vol. 10. Nairobi: T.S.C

Oloo, O. (2010). The Role of Teachers in Students Academic Performance in Bondo Districts. Unpublished M, Ed Thesis, Egerton University, Njoro, Kenya.

Owen, J.E. (2001). Education and Development in Kenya: A Historical Perspective. Nairobi: Oxford University Press

Otieno, S. (2010). TSC Wants The Government to Hire 66,3003 Teachers. East Africa Standard, p23. 9th June.

Orodho, A.J and Kombo, D.K. (2002). Research Methods. Nairobi: Kenyatta University, Institute of Open Learning.

Opolot, P.A. (2006). Mastery of modern school administration- Unpublished Med.Thesis. Makarere University, Uganda.

Owalabi, J (2007). Policy Making and Educational Policy Analysis. (3rd ed). Uganda: Makerere University Printers.

Owalabi, J. (2005). Policy Making and Educational Policy Analysis. (2nd Ed). Uganda: Makerere University Printers.

Ozigi, K.D. (2004). A Handbook of Personnel Management Practice in Ghana. Accra: Emage Publishing.

Porter, L. W. (2003). Motivation and Work Behavior. $7^{\text {th }}$ ed Boston: McGraw-Hill.

Republic of Kenya (2005). Kenya Education Sector Support Programme (2005 - 2010): Delivering Quality Education to all Kenyans. Nairobi: Government Printer.

Republic Of Kenya (2010). Sessional Paper No. 1 on Policy Framework for Education, Training and Research. Nairobi: Government Printer.

Rowan, G.A et al (2006). Philosophy and Education in Africa: An Introductory text for students of Education. Nairobi: Trans Africa press.

Rotter, A. (2002). Educational Psychology (6 $6^{\text {th }}$ Ed.). New York: Mc Graw Hill, Inc.

Robin, S. (2005). Management. $7^{\text {th }}$ Ed. New York: John Wiley \& Sons.

Richard I. A. (2008). Learning to Teach (2nd Ed.) New York: Mc Graw Hill, Inc.

Rice, N. (2006). Sessional Paper No. 1 on Policy Framework for Education, Training and Research. Nairobi: Government Printer.

Republic of Kenya, (1964). Kenya Education Report. Nairobi: Government Printer

Reyes, P. (2000). Organizational Commitment of Teachers In Their Workplaces: Commitment, Performance and Productivity. Newbury Park California: Sage Publications.

Sarah. Q.(2009). The Return of Grand Theory in Human Science, London Cambrige University Press.

Scott, L. W. (2003). Motivation and Work Behavior. $7^{\text {th }}$ ed Boston: McGraw-Hill.

Sifuna, D. N. (2006). An Introduction to History of Education (Revised Education). Nairobi: University of Nairobi

Ssemugenyi, S. (2006). TSC Roles out Hiring of 11,000 Teachers. Daily Nation, $26^{\text {th }}$ July, P.11

Sharma, B.A. (2004). Research Methods in Social Sciences. New Delhi: Sterling Publishers Ltd.

Teacher Service Commission, (2012). Kenya Education Report. Nairobi: Government Printer

Taylor W. (2000). Secondary Education in Africa, Developing Science Mathematics and ICT Education in Sub-Saharan Africa. Nairobi: UNESCO

Too, R (2007). Economic Survey Report. Nairobi: Government Printer.

Williams, P. (2009). Planning Teacher Demand and Supply. Paris: UNESCO

World Bank (2010). Education in Sub-Saharan Africa. Policies for Adjustment, Revitalization and Expansion. Washington, DC: IBRD

Wayne T. and Cecil R.(2008). Education in Sub-Saharan Africa. Policies for Adjustment, Revitalization and Expansion. Washington, DC: IBRD

Wamalwa, R.K (2010). The Role of Head Teachers and the Constraints. The Experience in the Guidance and Counseling of Students in Kenyan Secondary Schools: A case study of Kakamega District. Unpublished M, Phil. Thesis, Ergaton University, Eldoret, Kenya. World Bank (2011). Education in Sub-Saharan Africa. Policies for Adjustment, Revitalization and Expansion. Washington, DC: IBRD Yara, P. (2003). The Image of Education in 21st Century. Retrieved Oct. $2^{\text {nd }} 2010$ from http://www.emerging practices in education. com. 